\title{
The Role of Faults in Groundwater Circulation before and after Seismic Events: Insights from Tracers, Water Isotopes and Geochemistry
}

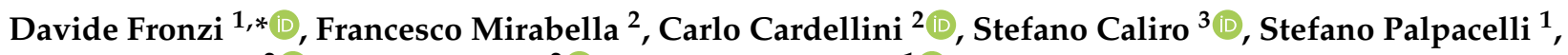 \\ Costanza Cambi ${ }^{2}$ (D) Daniela Valigi $^{2}\left(\mathbb{D}\right.$ and Alberto Tazioli ${ }^{1}{ }^{10}$ \\ 1 Department of Science and Matter Engineering, Environment and Urban Planning (SIMAU), \\ Marche Polytechnic University, Via Brecce Bianche 12, 60131 Ancona, Italy; paperino1990@libero.it (S.P.); \\ a.tazioli@staff.univpm.it (A.T.) \\ 2 Dipartimento di Fisica e Geologia, Università di Perugia, Via Pascoli s.n.c., 06123 Perugia, Italy; \\ francesco.mirabella@unipg.it (F.M.); carlo.cardellini@unipg.it (C.C.); costanza.cambi@unipg.it (C.C.); \\ daniela.valigi@unipg.it (D.V.) \\ 3 Istituto Nazionale di Geofisica e Vulcanologia, Sezione di Napoli, Osservatorio Vesuviano (INGV-OV), \\ Via Diocleziano 328, 80124 Naples, Italy; stefano.caliro@ingv.it \\ * Correspondence: d.fronzi@pm.univpm.it
}

check for updates

Citation: Fronzi, D.; Mirabella, F.; Cardellini, C.; Caliro, S.; Palpacelli, S.; Cambi, C.; Valigi, D.; Tazioli, A. The Role of Faults in Groundwater Circulation before and after Seismic Events: Insights from Tracers, Water Isotopes and Geochemistry. Water 2021, 13, 1499. https://doi.org/ 10.3390/w13111499

Academic Editor: Dongmei Han

Received: 28 April 2021

Accepted: 25 May 2021

Published: 27 May 2021

Publisher's Note: MDPI stays neutral with regard to jurisdictional claims in published maps and institutional affiliations.

Copyright: (c) 2021 by the authors. Licensee MDPI, Basel, Switzerland. This article is an open access article distributed under the terms and conditions of the Creative Commons Attribution (CC BY) license (https:// creativecommons.org/licenses/by/ $4.0 /)$.

\begin{abstract}
The interaction between fluids and tectonic structures such as fault systems is a muchdiscussed issue. Many scientific works are aimed at understanding what the role of fault systems in the displacement of deep fluids is, by investigating the interaction between the upper mantle, the lower crustal portion and the upraising of gasses carried by liquids. Many other scientific works try to explore the interaction between the recharge processes, i.e., precipitation, and the fault zones, aiming to recognize the function of the abovementioned structures and their capability to direct groundwater flow towards preferential drainage areas. Understanding the role of faults in the recharge processes of punctual and linear springs, meant as gaining streams, is a key point in hydrogeology, as it is known that faults can act either as flow barriers or as preferential flow paths. In this work an investigation of a fault system located in the Nera River catchment (Italy), based on geo-structural investigations, tracer tests, geochemical and isotopic recharge modelling, allows to identify the role of the normal fault system before and after the 2016-2017 central Italy seismic sequence (Mmax =6.5). The outcome was achieved by an integrated approach consisting of a structural geology field work, combined with GIS-based analysis, and of a hydrogeological investigation based on artificial tracer tests and geochemical and isotopic analyses.
\end{abstract}

Keywords: tracer tests; isotope hydrology; faults; carbonate aquifers; earthquakes; Mts. Sibillini; central Italy

\section{Introduction}

Nowadays, the role of fault systems in fluid transfer is a scientific challenging aspect, whose interest came into light again especially after the seismic shocks occurred in the last decades [1-3]. Many authors have focused their attention on the interaction between fault zones and drainage patterns [4], while others have tried to develop physical models to simplify and quantify how flow conditions are affected by fault zones [5-7]. A whole series of research works focus their attention on the fault behaviour in detail, joining hydraulic, temperature, other natural tracers data and borehole tests results [8] to better identify the reservoirs characteristics in close proximity of fault zones. Most of the works deal with fault systems and deep fluid transports in geo-structural fields for oil or hydrocarbon exploitation purposes while a smaller number of studies are focused on the impact of fault systems on groundwater flow [9]. Only a small number of these works actually deal with the changes in the role of a certain fault system before and after the seismic 
period [10]. However, the latter is really a crucial aspect in hydrogeological studies, especially when they concern groundwater management issues [11]. In fact, it is known that faults behave either as conduits or barriers with respect to groundwater flow depending on their kinematics and fault rock lithology [12,13], but the age-old problem of identifying if they limit or even block the flow of groundwater or if they rather act as a preferential flow path is partially still unsolved [14]. For instance, Bense et al. [8], in a review on fault zone hydrogeology suggest that the product of deformation processes accommodating strain can reduce or enhance the permeability within fault zones. In addition, earthquakes are known to cause changes in water chemical composition [15-17] and in springs' and rivers' discharge $[18,19]$. The connection between earthquakes and hydrodynamic changes has been verified and demonstrated by many authors in different countries [20-22].

These modifications in hydrodynamic behaviour are recognized at regional scales hundreds of kilometres away from the activating fault [23,24]. For example, [25] have found a clear correlation between earthquakes distance and magnitude in hydrogeological response of piezometric level fluctuations for 18 worldwide earthquakes. On the other hand, [26] recognized during the well-known Loma Prieta earthquake, significant hydrological changes in two basins located near field from San Andreas Fault, attributing the cause of these modifications to the formation of new fractures capable to develop novel continuous flow path or enhance existing continuous flow path. In Italy, some authors suggested different interpretations to explain groundwater modifications due to the main earthquakes occurred in the country [27-30]. As concerns the strongest earthquake occurred in Italy during the Amatrice-Norcia seismic sequence (August 2016-January 2017), some models were in fact proposed to justify the spring and river discharge change occurred in the area $[11,31,32]$. All the proposed models deal with observed springs and streams discharge variations before, during and after the seismic period [33-36]. In the same area [37] and [11] showed some correlation between discharge data and rainfall-snowfall events, coupling the latter with long time artificial tracer tests. Although many efforts were then made to suggest a preliminary hydrogeological conceptual model of the area after the seismic sequence, a specific study aiming to investigate the transfer of groundwater through fault zones in the northern portion of the area, adding some specific data to subsurface geology reconstruction has never been conducted before. The novelty of this work is therefore the connection of the field geo-structural methods and the hydrogeological investigations (namely tracer tests and geochemical and isotopic analyses), to show and prove how the role of faults is crucial in flow path modification, at local scale and after a seismic sequence. This integrated approach is useful to fill the gap in both disciplines, structural geology and hydrogeology, as methods of investigation in such areas usually work at different scales [8]. In particular, the aim of this work is to evaluate the role played, in groundwater circulation, by an active fault system located in a mountain area of central Italy (Mt. Sibillini) in which several earthquakes Mw > 5.0 occurred during the 2016-2017 seismic sequence $(\operatorname{Mmax}=6.5)[38-41]$.

\section{Materials and Methods}

\subsection{Study Area}

The study area is located in central Italy, in particular in the northern mountainous region of the Mts. Sibillini National Park. The geological domain is mainly characterized by the carbonate lithologies of the Umbria-Marche Stratigraphic Succession [42] and the hydrogeological features of the area are strictly influenced by the stratigraphic and tectonic setting [43-45]. In particular, the regional Basal aquifer complex (BAS) is hosted by the Upper Triassic-Lower Jurassic formation of Calcare Massiccio (600-700 m thick), a limestone deposed in a carbonate platform disarticulated in different domains, and by Corniola, a 150-400 m thick pelagic limestone formation. These formations overlie a Triassic dolomite and evaporite sequence acting as an aquiclude complex (TRI) and are characterized by a well-developed karstic system [11,37]. BAS recharges several punctual springs and it is responsible for the discharge increasing along the watercourses due to the intersection 
between the riverbed and the saturated portion of the aquifer, resulting the so called linear springs characterised by high discharge, widely occurring in the entire Mts. Sibillini area.

The disarticulation of Lower Jurassic carbonate platform in different domains, due to an extensional tectonic stage, gave rise to horst and graben structures [46]. This caused different Upper Jurassic stratigraphic successions to be deposed (complete and condensed). The complete graben pelagic sequence is made by Rosso Ammonitico, Marne a Posidonia and Diaspri, with overall thickness ranging from 200 to $1000 \mathrm{~m}$, while the horst condensed pelagic sequence is made by Bugarone, about $50 \mathrm{~m}$ thick. At local scale only, the Upper Jurassic formations constitute an aquiclude complex (JUR) separating BAS from the above Maiolica aquifer complex (MAI), mainly composed by stratified micritic limestones 50-500 m thick (Lower Cretaceous). At regional scale, BAS and MAI can be stratigraphically in contact, constituting a single regional aquifer.

MAI is regionally separated from the Scaglia Calcarea aquifer complex (SCA, $500 \mathrm{~m}$ thick) by the aquiclude complex made by Marne a Fucoidi (MF), a marly limestone formation 50-100 m thick deposed in Middle Cretaceous. SCA is made by stratified limestones including two formations, Scaglia Bianca and Scaglia Rossa (Upper Cretaceous) and it is responsible for local groundwater recharge of linear or punctual springs of the area, such as it is MAI, when separated from BAS [45]. SCA is overlain by the Scaglia Variegata (Paleogene, $60 \mathrm{~m}$ thick) and by an Oligocene-early Miocene pre-flysch sequence, $100-300 \mathrm{~m}$ thick (Scaglia Cinerea, Bisciaro and Schlier, heteropic with Marne a Cerrogna), closing the Umbria-Marche Succession. These formations act as upper aquiclude complex (SVC) and are followed by the Flysch della Laga aquitard, 50-2000 m thick (Miocene-Pleistocene). Figure 1, modified from [46], shows the relationships between simplified stratigraphy, hydrogeological complexes and related hydrodynamic features (not in scale).

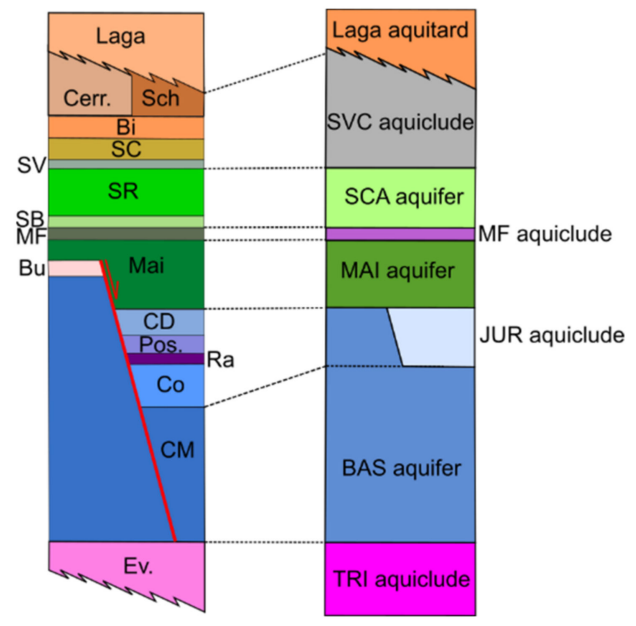

Figure 1. Sketch of relationships between the simplified stratigraphy (left) and hydrogeological complexes (right) (not in scale, modified from [46]. Legend of simplified stratigraphy (name, thickness and age of the formations): Ev: dolomite and evaporite sequence, indefinite thickness (Triass), CM: Calcare Massiccio, Co: Corniola, Rs: Rosso Ammonitico, Pos: Marne a Posidonia, Cd: Diaspri, Bu: Bugarone, Mai: Maiolica, MF: Marne a Fucoidi, SB: Scaglia Bianca, SR: Scaglia Rossa, SV: Scaglia Variegata, SC: Scaglia Cinerea, Bi: Bisciaro, Cer: Marne a Cerrogna, Sch: Schlier, Laga: Flysch della Laga. Hydrogeological complexes: TRI: Dolomitic-Evaporitic aquiclude, BAS: Basal aquifer, JUR Jurassic aquiclude, MAI: Maiolica aquifer, MF: Marne a Fucoidi aquiclude, SCA: Calcareous Scaglia aquifer, SVC: Upper aquiclude.

The Umbria-Marche Succession, which hosts the above-mentioned aquifers, is characterized by a complex tectonic history which led to the present-day tectonic configuration. The sequence was affected by syn-rift extension in the Jurassic, which ended in the lower Cretaceous with deposition of MAI. The area was then involved in the Apennines orogeny which led to the formation of a fold-and-thrust belt with anticlines and synclines averagely 
spaced about three kilometres. The latest and still active extensional tectonic phase, with extension oriented SW-NE, began in the early Quaternary and created the present-day landscape, characterized by a set of normal faults bounded basins. The Quaternary faults are responsible for the present-day seismicity of the area, including the 2016-2017 seismic sequence. From a hydrogeological point of view, the seismic sequence triggered local transversal groundwater exchanges between aquifers belonging to different hydrostructures, separated from each other by the main extensional normal fault systems of the area [32]. Before the seismic sequence groundwater circulation was mainly northwest directed and parallel to these fault systems $[32,37,47,48]$. After the seismic sequence, occurred between 24 August 2016 and 18 January 2017 (nine Mw 5.0-6.5 seismic events), a prevalently westward transversal exchange between different hydro-structures was observed [32,37]. A general increase in river and springs discharge was recorded on the western and eastern slope of the Sibillini ridge, particularly in systems located in the northern part of the area, soon after the first seismic shock. After the second and third shocks, the discharge remained high on the western side and suddenly dropped in a few time on the eastern side, causing the disappearance of some springs [33].

This research focuses on the northern part of the Mts. Sibillini domain (Figure 2), for which the hydrogeological boundaries between different systems have never been clearly defined yet $[11,37,49]$. More in specific, the upper Nera River basin was analysed in this study (Figure 2). The basin extends for about $120 \mathrm{~km}^{2}$ and it can be divided into two sub-basins, namely Castelsantangelo creek and Ussita creek. The first extends for $80 \mathrm{~km}^{2}$ while the latter is $46 \mathrm{~km}^{2}$ wide. The main watercourse flowing in the Castelsantangelo basin (Castelsantangelo creek) is $10 \mathrm{~km}$ long and is characterised by the presence of two main springs and three linear springs emerging from the riverbed, fed by the main aquifers $[47,50]$. The watercourse flowing in the Ussita basin (Ussita creek) is about $11 \mathrm{~km}$ long. In this case also, discharge increases are observed along the stream stretches crossing the main aquifers (linear springs) [50]. The monitoring points for tracer tests and isotopic investigations are the main local punctual springs and at the end-point of the linear springs along the two watercourses (Figure 2).

\subsection{Tracer Tests}

The Mts. Sibillini area has been the setting of several long time and periodic artificial tracer tests conducted before, during and after the seismic period [11,36]. In each test, the Mèrgani sinkhole (point 1 in Figure 2) has been selected as tracer injection point. The sinkhole is located about $1300 \mathrm{~m}$ a.s.l. in the tectono-karstic depression of Pian Grande [51], which is a wide intra-mountain plateau, bordered by normal faults and filled by Holocenic fluvial-lacustrine deposits [52]. From a geomorphological point of view, the presence of a well-developed epikarstic system within the plain is highlighted by the occurrence of several dolines [53]. In this context, the Mèrgani sinkhole, located on the southern-western side of the plain, represents one of the most developed karstic phenomena.

The tracer tests have been performed by applying the sudden injection method and two kinds of tracers were selected and used alternately. During the first pilot tracer test, performed on 12 February 2016 (pre-seismic), $2 \mathrm{~kg}$ of Na-Fluorescein $\left(\mathrm{C}_{20} \mathrm{H}_{10} \mathrm{Na}_{2} \mathrm{O}_{5}\right)$ has been injected into the sinkhole.

The second test, performed on 9 June 2016 (pre and co-seismic), was characterized by the injection of $29 \mathrm{~kg}$ of Tinopal CBS- $\mathrm{X}\left(\mathrm{C}_{28} \mathrm{H}_{20} \mathrm{Na}_{2} \mathrm{O}_{6} \mathrm{~S}_{2}\right)$. The last three tracer tests were performed after the seismic period on 20 March 2017, 20 March 2018 and 8 February 2019, and consisted in the injection of $85 \mathrm{~kg}$ of Tinopal CBS-X, $16 \mathrm{~kg}$ and $27 \mathrm{~kg}$ of Fluorescein respectively. More specification about the inflow discharge in the Mèrgani sinkhole during the injection operations are reported in [11]. 


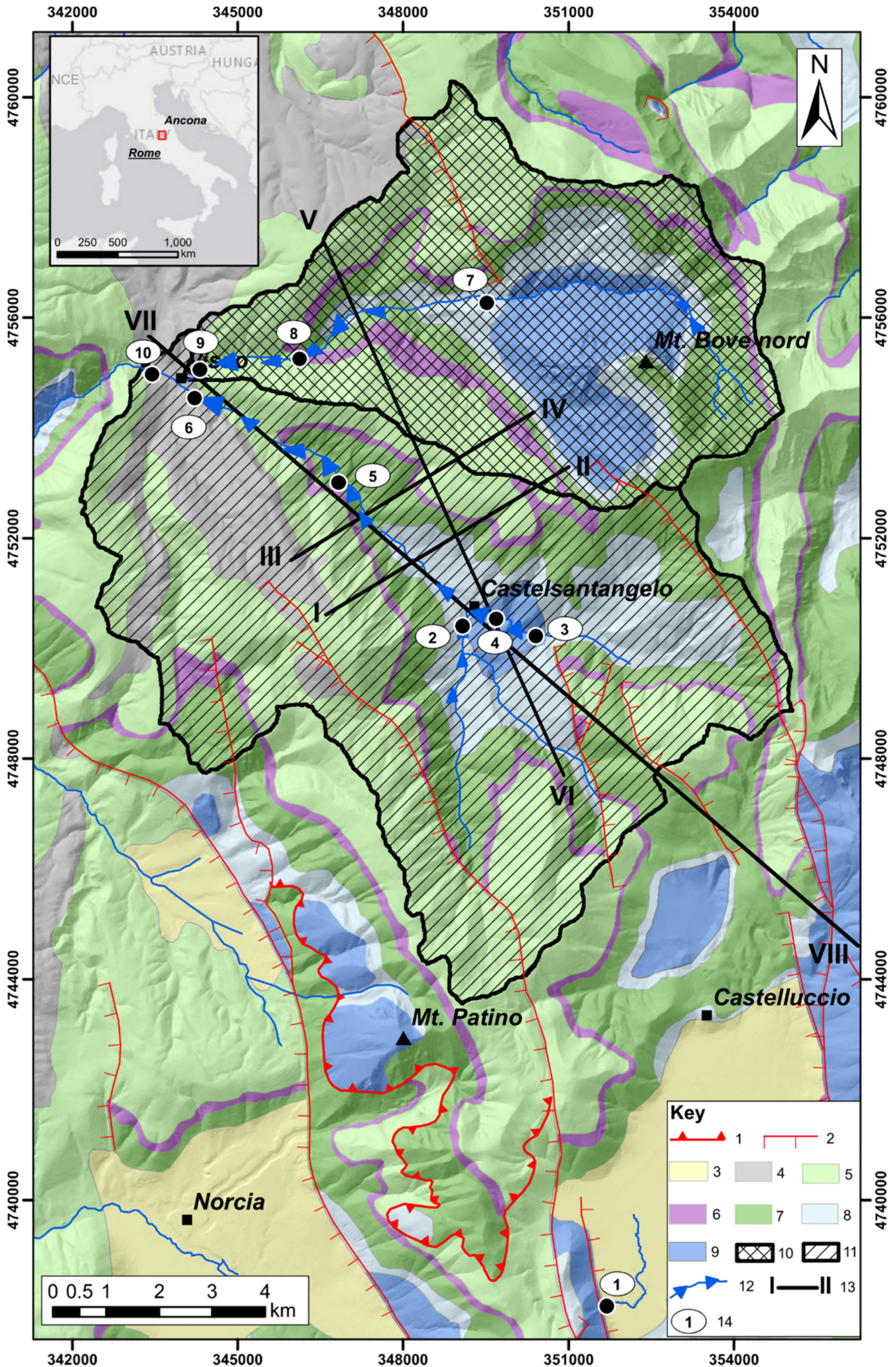

Figure 2. Hydrogeological complexes map and main tectonic lineaments of the study area modified from [46]. (1) Thrust fault (2) Normal fault (3) Quaternary deposits (4) Miocenic aquiclude (SVC) (5) Scaglia calcarea aquifer (SCA) (6) Marne a Fucoidi aquiclude (MF) (7) Maiolica aquifer (MAI) (8) Jurassic aquiclude (JUR) (9) Calcare Massiccio—Corniola Formations, Basal aquifer (BAS) (10) Ussita basin (11) Castelsantangelo basin (12) Linear spring (13) Trace of geological cross-sections. (14) Monitoring points. 
Each monitoring point in the two analysed basins was equipped with different tracer detection and measurement devices. The monitoring points location has been selected in accordance with the hydrogeological setting of the investigated area. In general, they are located at the end of the aquifers' outcrops along the riverbanks, in the proximity of the main linear springs belonging to the analysed streams.

In particular, point 4 was instrumented, during all the monitoring period, by a continuous fluorimetric probe produced by Albillia Co. (Neuchatel, Switzerland). The probe contains various optics for tracer detection, a standalone power supply and a data logger for the measured data storage. The Albillia GGUN-FL30 fluorometer used in this point is characterized by a minimum detection limit of $2 \times 10^{-11} \mathrm{~g} / \mathrm{mL}$. Measurements have been acquired every 10 min during the various tests. Point 8 , located in the Ussita creek, was instrumented by a model 3700C portable water sampler produced by Teledyne ISCO (Lincoln, Ne, USA). The sampler is a sequential collector with a specific time interval sampling which can be selected by the operator. For the various tests, the automatic sampling time was settled at $12 \mathrm{~h}$. All the other monitoring points have been instrumented by an active carbon trap used to fix tracer. Moreover, every 15 days, a water sample was collected manually in each monitoring point, during the substitution of fluorometric carbon-active traps. Both Tinopal CBS-X and fluorescein, were extracted by the carbon-active traps using a potassium hydroxide solution in methanol. Once collected, the water samples and the solutions obtained by the extraction were analysed by a model RF-6000 laboratory spectrofluorometer produced by Shimadzu Corporation (Milan, Italy). The calibration of the Shimadzu spectrofluorometer was performed by using three concentration standards $(10,20$ and $100 \mathrm{ppb})$ prepared using the same water collected in the field and a blank sample for each monitoring point, sampled before each new tracer injection.

\subsection{Isotopic Investigation and Geochemical Analysis}

With the aim to characterize the mean recharge elevation of the analyzed springs emerging along the streams, isotopic analysis of water has been conducted. Water samples were collected both at rainfall sampler, punctual springs and linear spring. Water samples for isotopes analysis were collected in $50 \mathrm{~mL}$ high-density polyethylene bottles sealed by plastic inserts to avoid water evaporation. Isotopic analyses of oxygen of the water were performed with: (i) a near infrared laser analyzer (L2130i, Picarro, Santa Clara, CA, USA) using the wavelength-scanned cavity ring down spectroscopy technique at the laboratory of INGV of Naples (analytical error $\delta^{18} \mathrm{O} \pm 0.08 \%$; data reported vs Vienna Standard Mean Ocean Water, V-SMOW), and (ii) at CNR-IGG.

The correlation between $\delta^{18} \mathrm{O}$ and the elevation was determined by eight rainfall samplers located mainly between $600 \mathrm{~m}$ and $974 \mathrm{~m}$ a.s.l., with the highest one located at $1800 \mathrm{~m}$ a.s.l. The meteoric bimonthly sampling was performed between 2013 and 2019 (Table 1) covering the entire hydrologic year. Standard precipitation gauges with funnel diameter of tot $\mathrm{cm}$ and 5" gauges $(12.72 \mathrm{~cm}$ of diameter) were used as rainfall sampler connected, by means of an externally insulated PVC pipe, to a buried totalizers constituted by $20 \mathrm{~L}$ volume tank. To avoid evaporation processes, a layer $(\sim 1 \mathrm{~cm})$ of pure paraffin oil was inserted in the tank between May and September. Precipitation amount recorded by the rain gauges was compared with the amount of water measured manually for each sampling period. The average $\delta^{18} \mathrm{O}$ values were determined by weighting the amount of the water collected by the rainfall sampler at each sampling respect to the total precipitation of the entire period of observation. To fill the gap between $974 \mathrm{~m}$ and $1800 \mathrm{~m}, 11$ minor punctual springs in the area have been selected. The small selected springs are characterized by a low flowrate during the entire hydrologic year and accordingly to their limited extensions and elevation of recharge area (not so different form the punctual spring altitude) and their rapid flow response to the rainfall events, they can be used as natural pluviometers [54-56]. All the minor springs were monthly sampled during the entire hydrologic year in 2017. 
Table 1. Sampling points (rainfall sampler or minor spring) used to determine the $\delta^{18} \mathrm{O}$ content at different elevation in the study area.

\begin{tabular}{cccc}
\hline Sampling Point Type & Sampling Period & Name & Elevation (m a.s.1.) \\
\hline $2017-2018$ & Cascia & 604 \\
& $2017-2019$ & Norcia & 700 \\
Rainfall samplers & $2013-2017$ & Castelsantangelo sul & 737 \\
& $2013-2017$ & Nera & 755 \\
& $2013-2017$ & Vallefiume & 805 \\
$2013-2017$ & Capodacqua & 930 \\
& $2013-2017$ & Foce & 974 \\
& $2013-2019$ & San Pellegrino & 1800 \\
\hline 2017 & Mt. Prata & 1093 \\
& 2017 & Prati di San Marco & 1267 \\
& 2017 & Fonte Acqua d'Abeto & 1299 \\
& 2017 & Fonte Secca & 1439 \\
& 2017 & San Lorenzo Basso & 1473 \\
Minor springs & San Lorenzo Alto & 1500 \\
& 2017 & Fonte dell'Asinella & 1520 \\
& 2017 & Fonte Conserva & 1557 \\
& 2017 & Fonte Civitella & 1577 \\
& 2017 & Fonte Utero & 1598 \\
& 2017 & Fonte del Grillo & 1645 \\
\hline
\end{tabular}

Geochemical analysis on the major chemical elements has been conducted in the punctual and linear springs located in the two sub-basins. The sampling and analyses were conducted following different methodologies. In particular, the pre-seismic sampling was performed between January and April 2016 and the chemical analyses were performed at Università Politecnica delle Marche using an ion chromatography system (ICS-1000, Dionex, Waltham, MA, USA), while the post-seismic sampling was performed between September 2016 and June 2020. In the period 2017-2019 sampling and analyses were performed at Perugia University. For these samples temperature, $\mathrm{pH}$, Eh, electrical conductivity and $\mathrm{HCO}_{3}$ were measured in the field. $\mathrm{HCO}_{3}$ concentration was determined by acid titration with $0.01 \mathrm{~N} \mathrm{HCl}$ using methyl orange as indicator. One of the sample aliquots was filtered upon sampling through $0.45 \mu \mathrm{m}$ membrane filters and then acidified with $1 \%$ of $1: 1$ diluted $\mathrm{HCl}$. Chemical analyses were performed at the laboratory of Perugia University. Calcium and $\mathrm{Mg}$ concentrations were determined by atomic absorption (AA) flame spectroscopy on the acidified sample while $\mathrm{Na}$ and $\mathrm{K}$ were determined by atomic emission (AE) flame spectroscopy, using an Instrumentation Laboratory aa/ae spectrophotometer $951 . \mathrm{Cl}$ and $\mathrm{SO}_{4}$ were determined by ion chromatography using a Dionex DX-120 instrument. The data of the monitoring point 3 have been integrated with bibliographic data from [57] which refers to periods both before and after the seismic period. The dataset used in this work is reported in the Supplementary Material (s1).

\subsection{Geological Field-Work and GIS-Based Analysis}

In order to characterize the geo-structural setting of the site, a detailed in field geostructural survey of the area was performed and synthetized along two geological crosssections across the Nera River (see trace in Figure 2). The survey was conducted using as base maps the 1:10.000 Regione Marche official map and the 1:40.000 geological map by [42] in an area of about $50 \mathrm{~km}^{2}$ manly focusing on the evidence of geo-structural elements connected with the groundwater circulation.

The structural geology information depicted during the fieldwork were integrated with the existing geological maps and a GIS repository has been developed with the aim to identify and clarify the groundwater-surface water interaction in the two monitored catchments. In particular, for each sub-catchment, the mean elevation was determined by 
the available digital terrain model (DTM, 10 meters' cell size) of the area. Subsequently, each hydrogeological complex outcropping in the area has been intersected with the DTM and the mean elevation for each complex for both basins was calculated. At last, a topographic intersection between the outcropping hydrogeological complexes and the streams were performed, to investigate the correlation between streams elevation, drainage and recharge areas. The mean elevation of each hydrogeological complex outcropping in the sub-basins determined by the GIS procedure are used in Sections 3.2 and 4 to observe the discrepancy to the mean recharge elevation achieved by the isotopic data for each linear spring analyzed.

\section{Results}

\subsection{Geo-Structural Approach}

The geo-structural survey revealed the presence of a previously unmapped normal fault whose strike roughly corresponds to the Nera River trace in the area. The fault (see outcrop location in Figure 3) strikes $N 170^{\circ}$ and dips to the SW at $42^{\circ}$. The fault kinematics is clearly normal and dip-slip as shown by the presence of calcite slicken-lines (Figure 3).

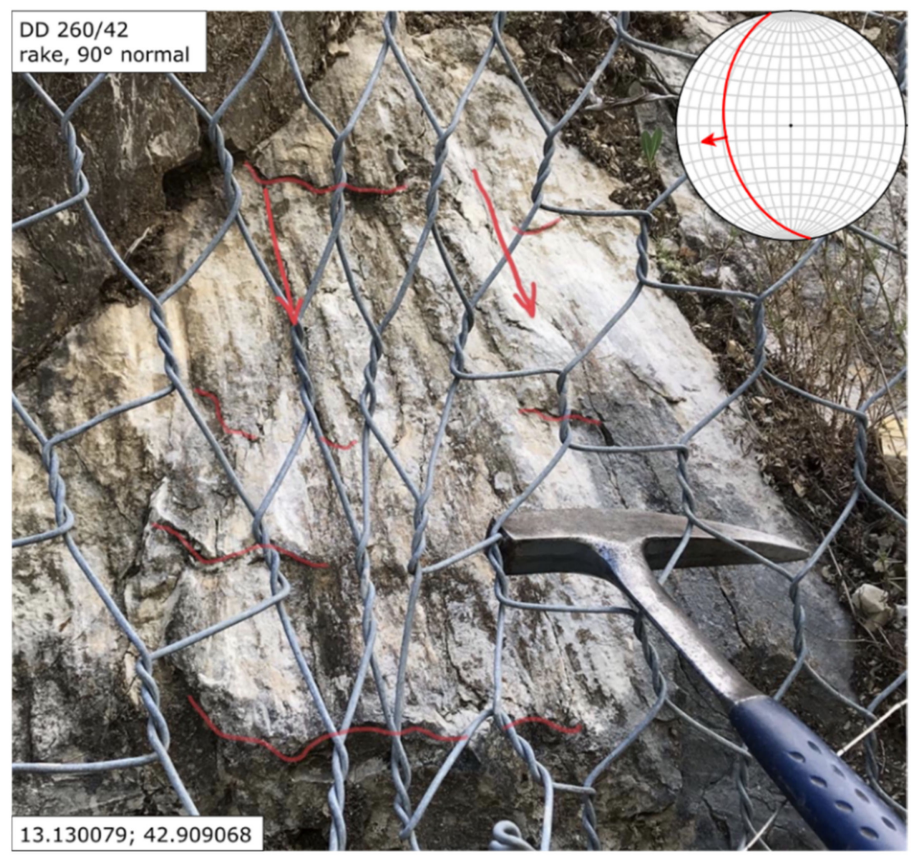

Figure 3. Outcrop of the new mapped fault with its kinematics represented in the stereo plot.

This is not a regional scale structure as it extends for a length in the order of 3-4 km. Nevertheless, the fault, which at surface affects mainly the Maiolica (MAI) and the Jurassic aquiclude (JUR), extends in the subsurface also dissecting the Calcare Massiccio (BAS) (Figure 4). 


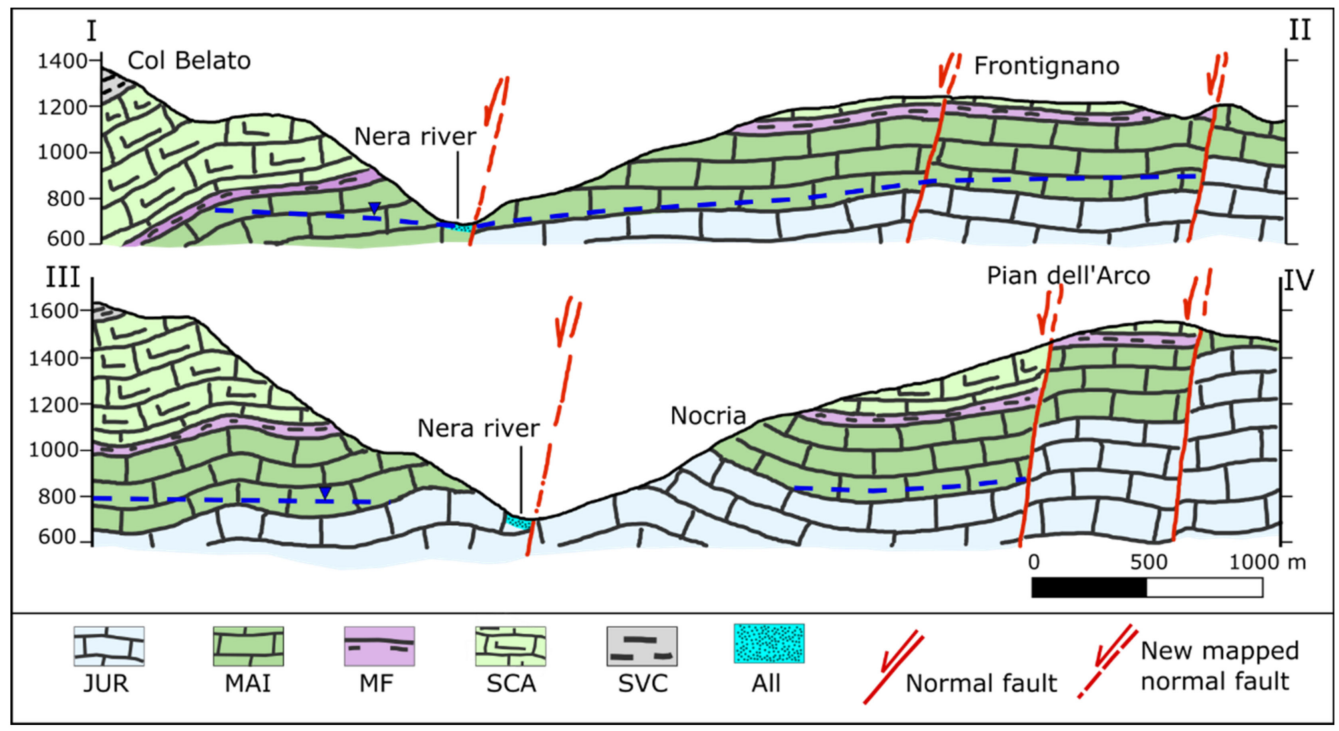

Figure 4. Hydrogeological cross sections with the identification of the new mapped fault and the hypothetic elevation (m a.s.l.) of water table. JUR (Jurassic aquiclude complex), MAI (Maiolica aquifer complex), MF (Marne a Fucoidi aquiclude complex), SCA (Scaglia Calcarea aquifer complex), SVC (Miocenic aquiclude complex), All (Holocenic alluvial deposits).

The GIS-based analysis highlights that the Ussita creek mean elevation is higher respect to the Castelsantangelo creek and so is the overall mean elevation of aquifer formations (Table 2). Nonetheless, the three hydrogeological complexes hosting the main aquifers in the U-M Succession (SCA, MAI and BAS) are distributed differently in the two sub-catchments in terms of mean outcropping elevation. In particular, as concerns the Ussita creek, the hydrogeological complex outcropping at the highest elevation (1440 m a.s.l.) is MAI, the basal aquifer (BAS) mean elevation is intermediate (1328 $\mathrm{m}$ a.s.l), while the SCA aquifer mean elevation is the lowest, (1213 m a.s.l.). In the Castelsantangelo creek, the BAS aquifer mean elevation is the lowest ( $862 \mathrm{~m}$ a.s.l.), the MAI aquifer mean elevation is intermediate (1278 $\mathrm{m}$ a.s.l.) and SCA aquifer outcrops at the highest mean elevation (1357 $\mathrm{m}$ a.s.l.).

Table 2. Mean and standard deviation values for the elevation of each basin and each aquifer outcropping into the study area determined by the GIS analysis.

\begin{tabular}{ccc}
\hline $\begin{array}{c}\text { Catchment/ Hydrogeological } \\
\text { Complexes }\end{array}$ & Mean Elevation (m a.s.l.) & Std. Dev. (m a.s.l.) \\
\hline Ussita creek $^{\text {DTM }}$ tot & 1291 & 377 \\
SCA & 1213 & 321 \\
MAI & 1440 & 451 \\
BAS & 1328 & 291 \\
AQUIFERS $_{\text {mean }}$ & 1327 & 354 \\
\hline Castelsantangelo creek $^{\text {DTM }}$ tot & 1245 & \\
SCA & 1357 & 301 \\
MAI & 1278 & 256 \\
BAS & 862 & 71 \\
AQUIFERS & 1165 & 219 \\
\hline
\end{tabular}

The higher elevation of the Ussita basin in respect to the Castelsantangelo one, is reflected also on the topographic cross section along the two streams (Figure 8b). The 
Ussita creek extends from $1225 \mathrm{~m}$ to $625 \mathrm{~m}$ a.s.l. while the Castelsantangelo creek extends from $1060 \mathrm{~m}$ to $625 \mathrm{~m}$ a.s.l.

As concerns the BAS aquifer, the Ussita creek intersects it from $1200 \mathrm{~m}$ to $790 \mathrm{~m}$ a.s.l., at a higher elevation than the Castelsantangelo creek, which intersects the same aquifer from $830 \mathrm{~m}$ to $730 \mathrm{~m}$ a.s.l. As concerns the MAI aquifer, the Ussita creek crosses it from 720 to $700 \mathrm{~m}$ a.s.l. and from $685 \mathrm{~m}$ to $660 \mathrm{~m}$ a.s.l. (with a short interruption caused by the stream intersection with the JUR aquiclude) while the Castelsantangelo creek intersects it between $711 \mathrm{~m}$ and $670 \mathrm{~m}$ a.s.l. Therefore, the mean outcrops elevations are quite similar among each other. The SCA aquifer outcrops along the Ussita creek between $660 \mathrm{~m}$ and $620 \mathrm{~m}$ a.s.l. while in the Castelsantangelo creek the same aquifer outcrops from $665 \mathrm{~m}$ to $650 \mathrm{~m}$ a.s.l., so that the aquifer mean elevation is slightly higher in the Castelsantangelo catchment, despite its lower mean elevation. Just $500 \mathrm{~m}$ before their confluence near the Visso village, both streams intersect the SVC aquiclude.

\subsection{Isotope Hydrology and Geo-Chemical Approaches}

The relation $\delta^{18} \mathrm{O}$-elevation determined by the weighted $\delta^{18} \mathrm{O}$ content obtained for the rainfall samples and for the water samples of the minor springs of the area (used as rain gauge due to the characteristics expressed in the paragraph 2.3) is shown in Figure 5. The isotopic altitude gradient of $0.27 \%$ / $/ 100 \mathrm{~m}$ has been calculated by the linear fit of the $\delta^{18} \mathrm{O}$ dataset with a strong correlation, as suggested by the Pearson coefficient of determination $\left(\mathrm{R}^{2}=0.81\right)$. The gradient obtained is quite similar to the one determined by [58] for central Italy $(0.20 \%$ o $/ 100 \mathrm{~m})$ and by [59] for the same area in 2006 (Figure 5).

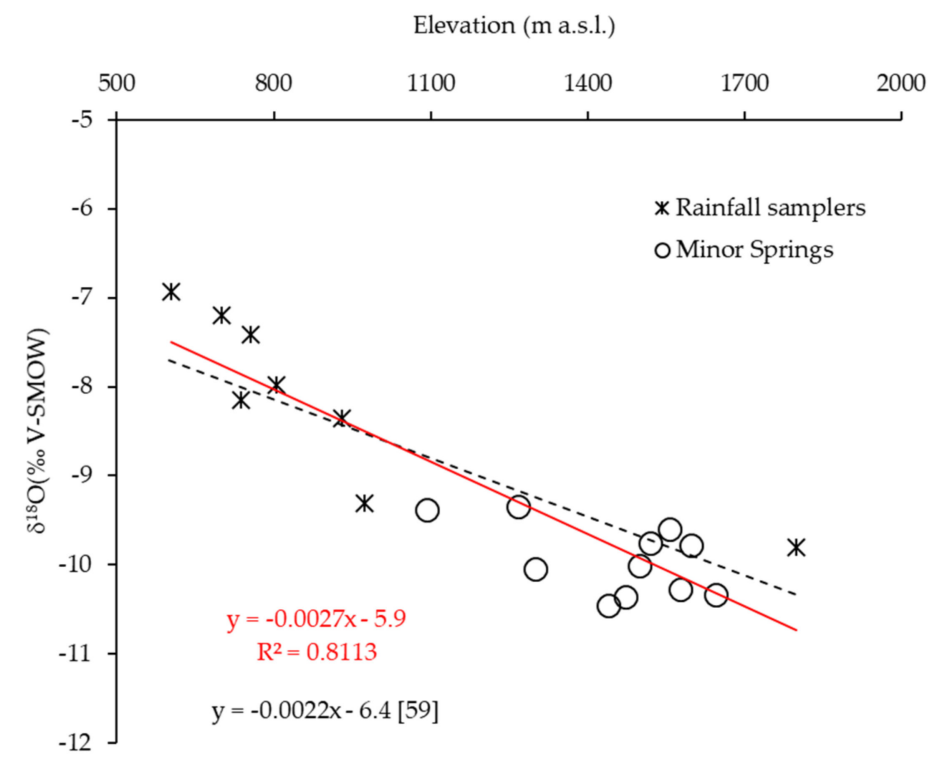

Figure 5. Linear regression between $\delta^{18} \mathrm{O}$ and elevation determined by eight rain gauges' water collectors and eleven minor springs of the area obtained in this study (red solid line) and linear regression obtained by [59] for the same area (black dashed line).

Based on Langelier-Ludwig diagram (Figure 6), water from the punctual and linear springs of the Ussita and Castelsantangelo basins can be classified mainly as $\mathrm{HCO}_{3}-$ $\mathrm{Ca}(\mathrm{Mg})$ type. This result, observed previously by [60] reflects the groundwater interaction with the carbonate host rocks belonging to the U-M Sedimentary Succession. Operating an appropriate magnification of the diagram (Figure 6b) it is possible to highlight the presence of at two types of water: one characterized by a low value of $\mathrm{SO}_{4}$ (points 2, 3 and 7) and the other by relatively higher values of $\mathrm{SO}_{4}$ (points 4,5 and 8). This suggests the presence of a sulphate rich component ascribable to the interaction of groundwater with the upper portion of the Triassic dolomites/evaporites (TRI) underlying the U-M Succession (Figure 1). Other sources of sulphates like anthropogenic pollutants can be neglected, 
in fact, according to the Corine Land Cover 2018 (CLC, 2018) there are no agricultural activities in the area and the presence of some fish farms is not responsible for the increase of the $\mathrm{SO}_{4}$ concentration as reported in [61].

a)

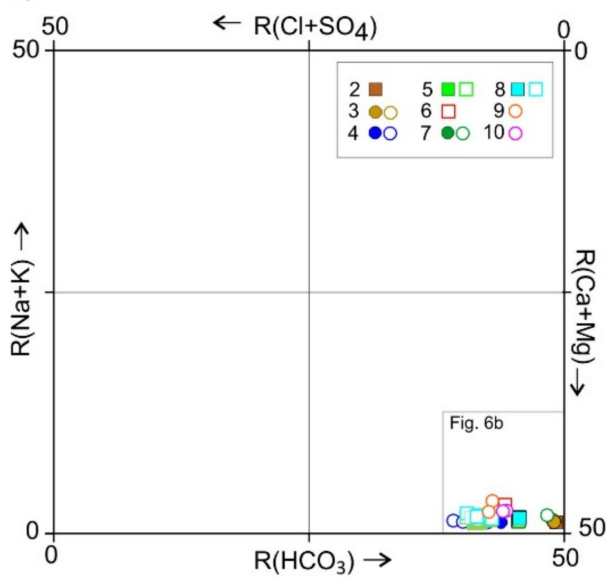

b)

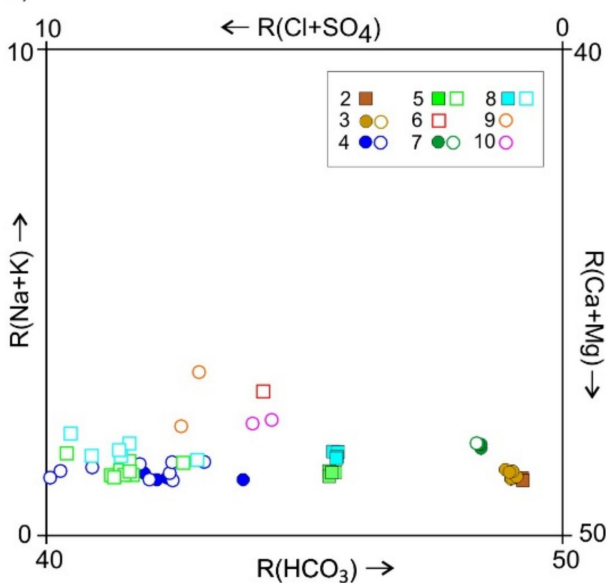

Figure 6. (a) The plot of the chemical composition of upper Nera River monitoring points (pre, filled symbols and post seismic, empty symbols) on the Langelier-Ludwig diagram. (b) Detail of the Langelier-Ludwig of referring to the box reported in (a).

In both the analyzed basins, the $\mathrm{SO}_{4}$ content shows variations moving downstream of the two basins (Figure 7a). In particular, for the Castelsantangelo creek an increase in $\mathrm{SO}_{4}$ content is observed moving from point 3 to point 4 , while a slight decrease in $\mathrm{SO}_{4}$ is recorded between point 4 and 5 . This decrease in $\mathrm{SO}_{4}$ reduces after seismic period as pointed out by Figure $7 \mathrm{~b}$, reporting the variation of $\mathrm{SO}_{4}$ during the sampling period. In fact, while only a slightly increase of $\mathrm{SO}_{4}$ is observed at point 4 after the seismic period, at point 5 the $\mathrm{SO}_{4}$ content is doubled passing from a mean value of $12.6 \mathrm{mg} / \mathrm{L}$ to a mean value of $24.4 \mathrm{mg} / \mathrm{L}$.

As concerns the Ussita creek, before the seismic sequence it is possible to identify a slight increase in $\mathrm{SO}_{4}$ moving downstream from point 7 to point 8 from about $3.3 \mathrm{mg} / \mathrm{L}$ to $11.2 \mathrm{mg} / \mathrm{L}$. After the seismic period the point 8 is characterized by a doubling in $\mathrm{SO}_{4}$ content. Moving downstream from the point 5 to the point 6 of the Castelsantangelo creek and from the point 8 to the point 9 of the Ussita creek, the $\mathrm{SO}_{4}$ water content shows a slight decrease possibly due to the input into the streams of $\mathrm{SO}_{4}$ poor groundwater from the SCA aquifer [55]. This aspect is supported by the presence of a linear spring between point 8 an 9 (Figure 2).

A mean recharge elevation for the punctual and linear springs monitored in this study was obtained by applying the $\delta^{18} \mathrm{O}$-elevation correlation (Figure 5 ) to the $\delta^{18} \mathrm{O}$ water content evaluated during the sampling period (Table 3 ). 
Table 3. Sulphate content and isotopic $\delta^{18} \mathrm{O}$ value ( \pm standard deviation) and mean recharge elevation obtained from the $\delta^{18} \mathrm{O} /$ elevation correlation for each monitoring point (Figure 2). The data refers to the pre-seismic and the post-seismic period respectively, (-) data not available.

\begin{tabular}{|c|c|c|c|c|c|c|}
\hline \multirow[b]{2}{*}{ No. on Map } & \multicolumn{3}{|c|}{ Pre-Seismic Period } & \multicolumn{3}{|c|}{ Post-Seismic Period } \\
\hline & $\begin{array}{l}\mathrm{SO}_{4}{ }^{2-} \pm \sigma \\
(\mathrm{mg} / \mathrm{L})\end{array}$ & $\begin{array}{c}\delta^{18} \mathrm{O} \pm \sigma \\
(\% \text { V-SMOW) }\end{array}$ & $\begin{array}{l}\text { Elevation } \\
\text { (m a.s.l.) }\end{array}$ & $\begin{array}{l}\mathrm{SO}_{4}{ }^{2-} \pm \sigma \\
(\mathrm{mg} / \mathrm{L})\end{array}$ & $\begin{array}{c}\delta^{18} \mathrm{O} \pm \sigma \\
(\% \text { V-SMOW) }\end{array}$ & $\begin{array}{l}\text { Elevation } \\
\text { (m a.s.1.) }\end{array}$ \\
\hline 2 & $1.43 \pm 0.06$ & $-9.62 \pm 0.07$ & 1356 & - & $-9.57 \pm 0.05$ & 1341 \\
\hline 3 & $1.78 \pm 0.09$ & $-9.7 \pm$ n.a. & 1379 & $1.58 \pm 0.16$ & $-9.63 \pm 0.15$ & 1359 \\
\hline 4 & $21.3 \pm 0.28$ & $-10.25 \pm 0.15$ & 1545 & $25.2 \pm 3.32$ & $-10.34 \pm 0.23$ & 1572 \\
\hline 5 & $12.6 \pm 0.17$ & - & - & $24.4 \pm 2.33$ & $-10.16 \pm 0.25$ & 1518 \\
\hline 6 & - & - & - & $16.87 \pm$ n.a. & $-10.04 \pm 0.33$ & 1482 \\
\hline 7 & $3.34 \pm 0.06$ & - & - & $2.7 \pm$ n.a. & $-10.01 \pm$ n.a. & 1473 \\
\hline 8 & $11.2 \pm 0.23$ & $-10.19 \pm 0.11$ & 1526 & $24.2 \pm 3.1$ & $-10.15 \pm 0.33$ & 1514 \\
\hline 9 & - & - & - & $22.1 \pm 1.32$ & $-9.88 \pm 0.18$ & 1434 \\
\hline 10 & - & - & - & $17.9 \pm 0.75$ & $-10.00 \pm 0.03$ & 1470 \\
\hline
\end{tabular}
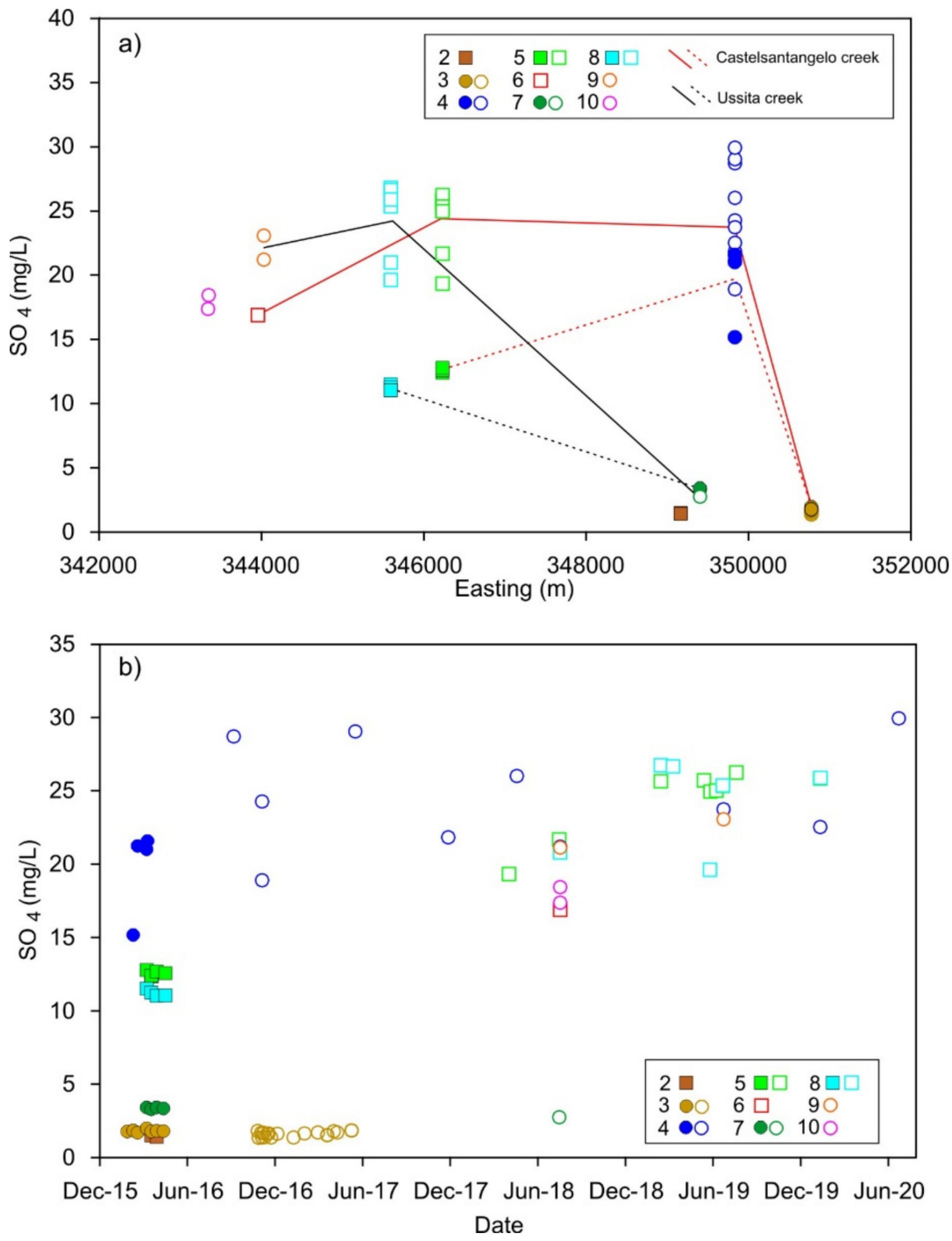

Figure 7. (a) $\mathrm{SO}_{4}$ content (mg/L) of the water sample of the monitoring point (pre: filled symbols and post seismic: empty symbols) moving downstream the two analyzed basins. The lines represent the trend of the average $\mathrm{SO}_{4}$ content (Table 3) on the monitoring points (the dashed line represents the pre seismic, while the solid one represents the post-seismic period). (b) $\mathrm{SO}_{4}$ content (mg/L) on the water sample of the monitoring point (pre: filled symbols and post seismic: empty symbols) vs. sampling period. 
In general, before the seismic period, a different $\delta^{18} \mathrm{O}$ content is observed between point 2 and 3, similar among each other, and point 4 even if they all emerge from the BAS aquifer complex. In particular, the point 2 and 3 show a more likely local recharge area with a mean elevation of 1356-1379 m a.s.l. in respect to the point 4 which is characterized by a higher recharge area (1545 $\mathrm{m}$ a.s.l.). The mean BAS elevation outcropping upstream the point 4 in the Castelsantangelo basin, determined by the GIS analysis, is equal to $862 \mathrm{~m}$ a.s.l. and this value, if compared with the one determined by the isotopic $\delta^{18} \mathrm{O}$ content, suggests a contribution of groundwater external from its hydrologic basin. The monitoring point 8 shows a mean $\delta^{18} \mathrm{O}$ content of $-10.19 \%$ suggesting a mean elevation recharge area of about $1526 \mathrm{~m}$ a.s.l. During the post seismic period a more complete dataset allowed for the mean elevation recharge area evaluation for all the monitoring points (Table 3). Points 2 and 3 located in the upper part of the Castelsantangelo creek, both emerging from the BAS aquifer, are characterized by a quite similar $\delta^{18} \mathrm{O}$ content, thus indicating a mean elevation recharge area between 1330 and $1400 \mathrm{~m}$ a.s.l., similar to the pre seismic period. The point 4 is characterized, also during the post seismic period, by a less enriched $\delta^{18} \mathrm{O}$ content with respect to point 2 and 3 , and also in this case a contribution of groundwater from the external area can be supposed. Moving downstream from point 4 to point 6 along the Castelsantangelo creek, the mean elevation recharge areas seems to decrease, being approximately near $1500 \mathrm{~m}$ a.s.l., even much higher than the hydrogeological complexes outcropping in the basin. As concerns the Ussita creek, a slight increase in mean recharge elevation area is observed between point 7 and 8 , and this result is in accordance with the GIS based analysis showing that the BAS mean elevation, upstream to the point 7, outcrops at $1328 \mathrm{~m}$ a.s.l. while the MAI mean elevation, upstream to the point 8 , outcrops at $1440 \mathrm{~m}$ a.s.l. Moving downstream from point 8 to point 9 a decreasing in $\delta^{18} \mathrm{O}$ content shows a lower mean elevation recharge area. Also in this case the isotopic result is in accordance with the GIS based analysis (Table 2).

\subsection{Tracer Hydrology Approach}

The graphical results of the tracer tests are reported in the map of Figure 8a. In particular, the main schematic flow paths from the Mèrgani sinkhole towards the analysed basins (represented by the green arrows), highlight the hydrogeological connection between the Pian Grande plain and points 4 and 5, located along the Castelsantangelo creek.

As concerns the other monitoring points, the tracer has never been recorded neither before, during nor after the seismic period. This outcome is also confirmed by no tracer detection by the active carbons in any point.

Regarding Points 4 and 5 (Figure 9), they are characterized in particular by a decoupled time and quantity of tracer arrivals. As concerns the first tracer test (injection of 12 February 2016), point 4 is characterized by a concentration peak of about $4 \mathrm{ppb}$ (Figure 9a, principal vertical axis). A similar quantity of tracer has been recorded by the fluorometric probe between the 30 and 31st March 2016 (Figure 9a, principal vertical axis). During the same tracer test, a punctual water sample collected on 8 March 2016 in point 5 showed a tracer presence of about $234 \mathrm{ppb}$ (Figure 9b, secondary vertical axis). 

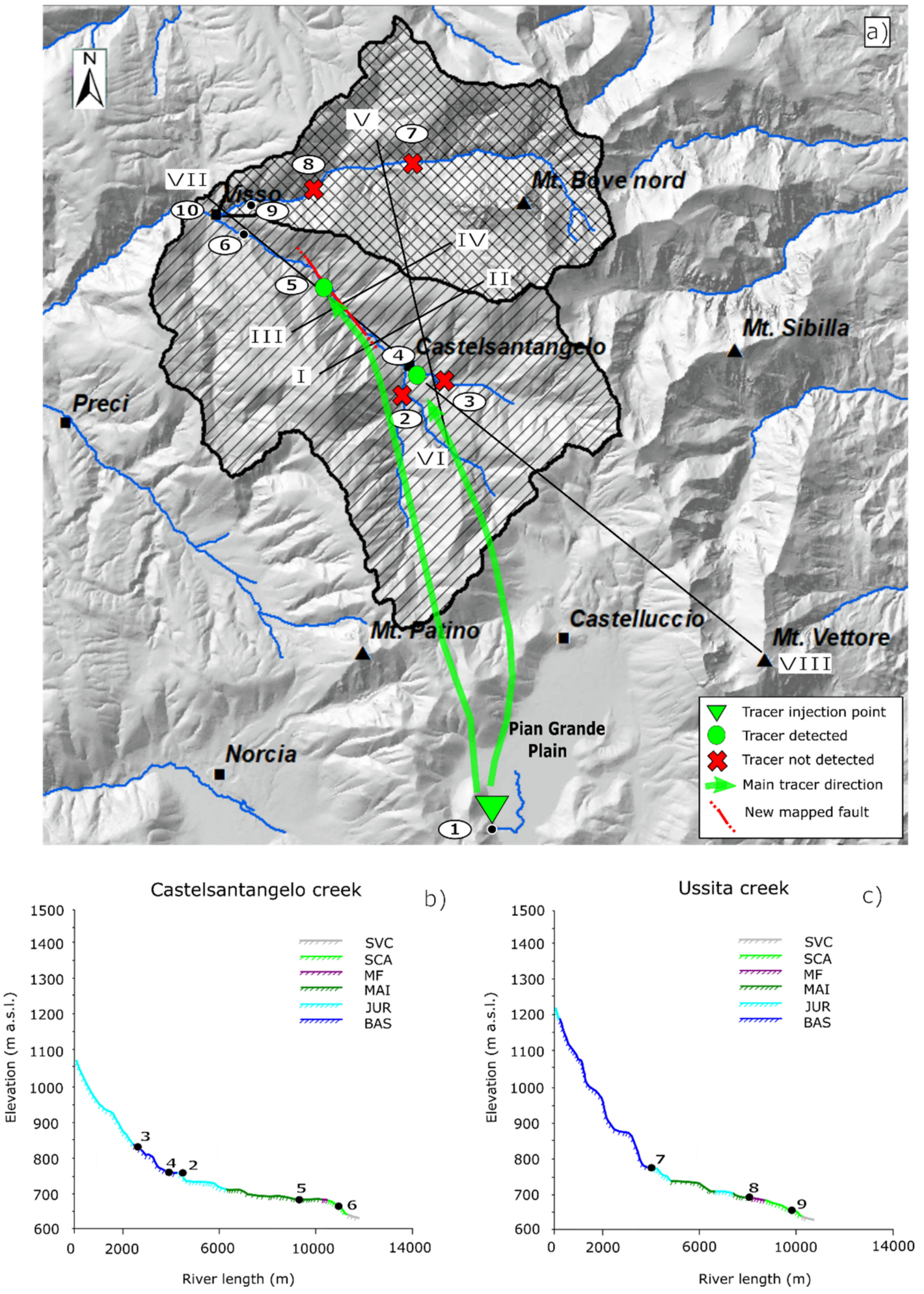

Figure 8. (a) Location of the new mapped fault and main tracer direction from injection point (point 1 in the map in Figure 2) to the analysed basins. The green dots refer to the point where the tracer has been recovered (point 4 and 5) while the red crosses refer to the monitoring point where the tracer has not been detected in this study (point 2, 3, 7 and 8). The monitoring point 6,9 and 10 are not instrumented for tracer detection. $(\mathbf{b}, \mathbf{c})$ Streams topographic intersection with the hydrogeological complexes and localization of the monitoring points for the analyzed basins: (b) Castelsantangelo creek (c) Ussita creek. 


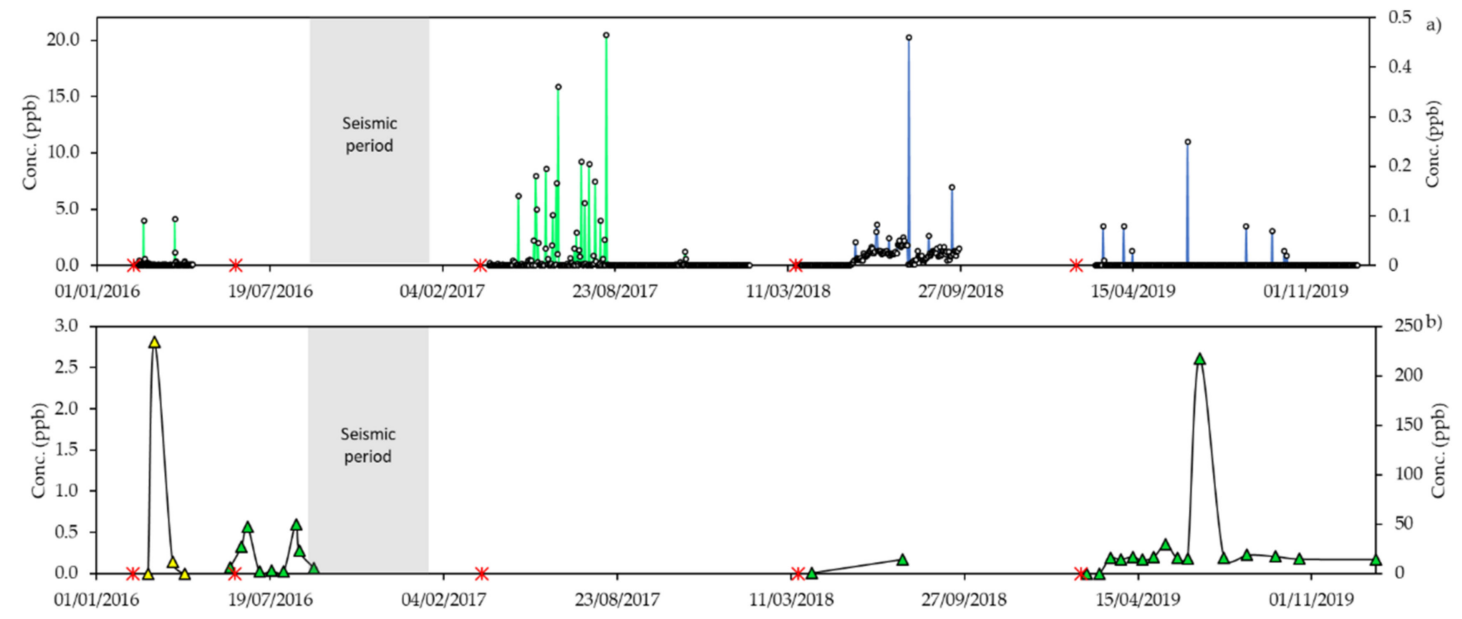

Figure 9. Tracer Breakthrough Curves of tests performed in the area starting from February 2016 (pre -seismic period) until December 2019. (a) Tracer recovered at the Castelsantangelo sul Nera linear spring (point 4 in Figure 2). The principal vertical axis refers to the green line, while the secondary vertical axis refers to the blue line. (b) Tracer concentration measured in punctual samples (point 5 in Figure 2). The principal vertical axis refers to the yellow symbols, while the secondary vertical axis refers to the green ones.

The decrease in tracer concentration following this peak in point 5 was recorded in the water sample collected on 29 March 2016, with a tracer concentration of $11.5 \mathrm{ppb}$. The second and the third tracer tests show some tracer arrivals in the Castelsantangelo creek (points 4 and 5), while no tracer was recorded in all the other monitoring points. In particular, during the second tracer test a bimodal behaviour in the tracer arrivals at point 5 is recognised (Figure 9b, principal vertical axis). The third tracer test (after the seismic period) shows several tracer peaks recorded at point 4 (Figure 9a, principal vertical axis).

As concerns the fourth tracer test (20th March 2018), a general decrease in concentration of tracer recorded at point 4 is observed with respect to that detected just after the seismic period during the third test. In particular, several peaks of tracer occurred from about two months after the injection. The main peak was recorded by the fluorometric probe on 27 July 2018 (Figure 9a, secondary vertical axis). At the same time, a slight increase of tracer concentration was observed at point 5 (Figure $9 \mathrm{~b}$, principal vertical axis). The last tracer test, conducted more than two years later than the seismic period (8 February 2019), shows a slight decrement of tracer peak concentration recorded at point 4 with respect to the previous tracer tests, according to the general decrease of springs and rivers discharge occurred after a first stage of growth [37] (Figure 9a secondary vertical axis). On the contrary, in point 5 a higher concentration of tracer was recorded with respect to that measured up stream (point 4 ), with the main peak showed by the water sample collected on 25 June 2019 (Figure 9b, principal vertical axis).

The Tracer Breakthrough Curves of point 4 and 5 show a decoupling in time of tracer arrivals and quantity each other, and this aspect is well evidenced in the first and the last tracer tests. In particular, point 5 is characterised by several peaks showing higher tracer concentration values respect to point 4 .

\section{Discussion}

The coupled use of both the approaches (hydrogeological and a geo-structural) in the upper Nera River basin, allowed for a detailed conceptual model achievement in the study area. In particular, a difference between the two analyzed basins is observed in respect to the geo-structural features which deeply influence the hydrogeological response and behaviour of the streams. In the Ussita creek catchment, BAS has higher geo-structural elevation (horst) with respect to the regional BAS, as noticeable in the hydrogeological section of Figure 10. For this reason, the recharge of the Ussita stream's springs seems to be not strictly connected to the regional basal flow (S-N oriented). 


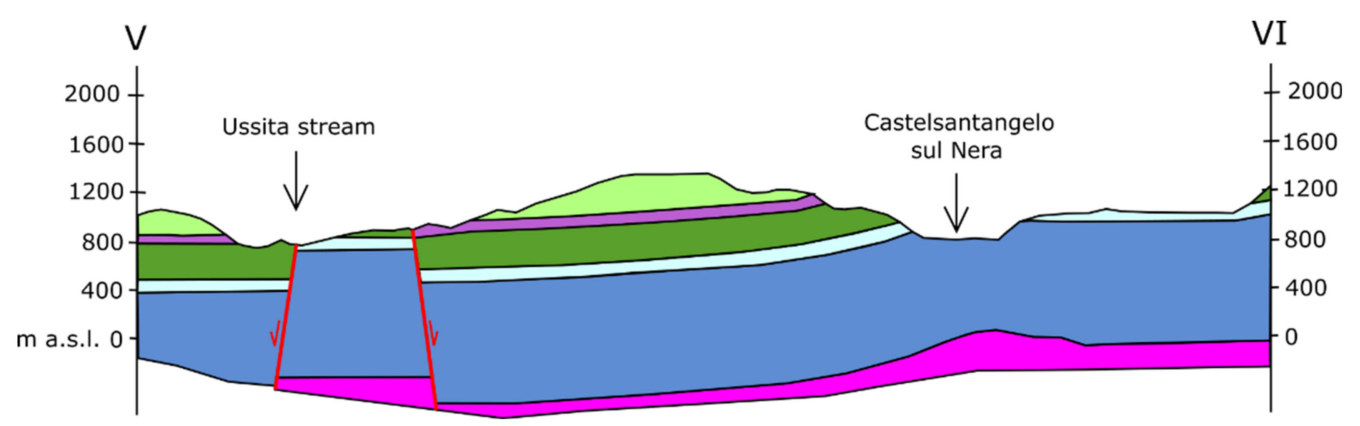

Figure 10. Hydrogeological cross-section (SSE-NNW oriented) modified from [49]. The colors in section refers to the sketch of hydrogeological complexes reported in Figure 1.

Moreover, accordingly to the GIS analysis a general higher topographic elevation is observed in the Ussita sub-basin in respect to the Castelsantangelo one. This is apparent also in the linear springs of the Ussita creek, which are located at higher elevation than those emerging along the Castelsantangelo creek. The tracer tests analysis supports this hydrogeological configuration. In fact, tracers have never been detected in the Ussita sub basin (points 7 and 8) neither before nor after the seismic sequence indicating that the groundwater recharge area of the Ussita creek is comparable to its catchment. On the contrary tracer has been detected both in point 4 and 5 indicating that there is a connection between the Castelsantangelo creek and areas outside its catchment both before and after the seismic period.

The new mapped fault seems to have a remarkable role on the groundwater path feeding the Castelsantangelo creek. In fact, the first and the last tracer tests highlights a decoupled behaviour in quantity and time of tracer arrivals in points 4 and 5, thus suggesting that the new mapped fault can act as preferential flow path along its strike, and groundwater coming from the Pian Grande Plain (point 1-see Figure 8a) is directed towards the point 5 located near the fault. On the contrary, the connection between point 1 and point 4 seems to be limited to the BAS aquifer as suggested by the cross-section SE-NW directed in Figure 11.

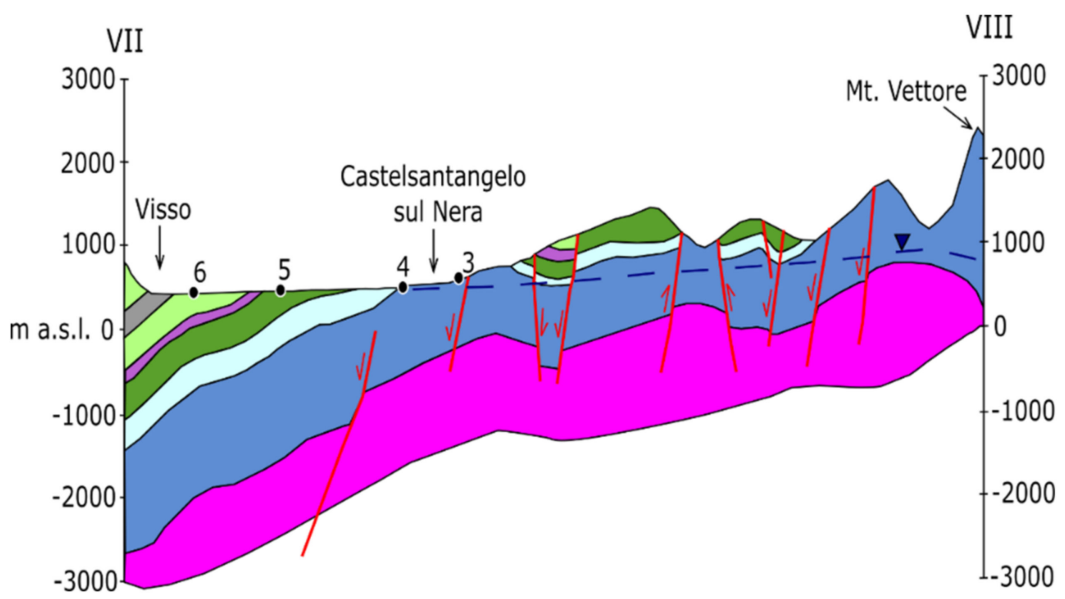

Figure 11. Hydrogeological cross-section (SE-NW oriented) modified from [37] with the hypothetic elevation of water table and the monitoring points along the Castelsantangelo stream. The vertical scale is exaggerated to better visualize the piezometric gradient, the colors in section refers to the sketch of hydrogeological complexes reported in Figure 1.

This hypothesis is in accordance with the lower tracer concentration in point 4 justified by the higher dilution of tracer within the regional BAS aquifer. The new mapped fault can be considered as a minor tectonic feature in relation to the regional ones, but a local 
influence on groundwater circulation has been observed and it represents a non-negligible geo-structural element in relation to local groundwater flow.

The low value of $\mathrm{SO}_{4}$ recorded before the seismic sequence at points 7, 8 (Ussita creek) with respect to the point 4 in the Castelsantangelo creek confirms that the water emerging in the Ussita creek is not involved in the deep groundwater circulation interacting with the evaporitic TRI aquiclude below the Mt. Vettore-Pian Grande Plain, characterized by high $\mathrm{SO}_{4}$ concentration due to the leaching of the Triassic evaporites [62].

The increase of $\mathrm{SO}_{4}$ concentration recorded both in point 5 and 8 after the seismic sequence seems to be relate to different mechanisms.

The new mapped fault favoured a connection between the BAS aquifer of Mt. VettorePian Grande Plain area (rich in $\mathrm{SO}_{4}$ ) and point 5 as it acted as a preferential flow path.

In contrast, the $\mathrm{SO}_{4}$ increase observed in point 8 is likely related to the tectonic displacement of Mt. Vettore-Mt. Bove fault system during the seismic sequence. This fault system, acting as a flow-barrier during the pre-seismic period, became responsible for the connection between the eastern sector of the Mt. Sibillini domain and the western portion [32], and in the high structural of Mt. Bove in which the Ussita basin develops, it caused an increase in $\mathrm{SO}_{4}$ at point 8 not connected to tracer arrivals.

The isotopic data for the monitoring spring of the area, coupled with the tracer tests and the geochemical data also permitted to observe a deep difference between the analyzed basins.

Although it is known that in the epikarst of the carbonate areas, infiltration water may stagnate for a long time in micro fissures, resulting in increasing mineralization and isotope differentiation [63-65], this does not seem the case of the investigated area. In fact, the research area is characterised by a well-developed surficial epikastic system only in the proximity of the Pian Grande Plain [53] and the infiltrating water, which can remain stagnant in the deepest fissures and micro fissures of the rock and therefore not affected by the evapotranspiration processes, is quickly remobilized when a rainfall event take place. After all, the study area is characterized by a well-developed karst and fissured system of both saturated and unsaturated zone, which guarantees a rapid infiltration process down to the saturated zone. Also [63] indicates that the stagnant water in the upper most part of the vadose zone is observed only where a high porosity contrast exists throughout the underlying bedrock. According to [37] the infiltration processes of meteoric water in this area are as fast as the water movement within the aquifers. Moreover, in the same area, [11] shows quick time response between the precipitation events and the spring discharge increasing, by performing sliding windows cross-correlation between rainfall, spring discharge and tracer concentration.

The $\delta^{18} \mathrm{O}$ water content measured in point 4 and 7 , respectively in the BAS aquifer of Castelsantangelo and Ussita, indicate that the recharge area elevation of Castelsantangelo is around $1572 \mathrm{~m}$ a.s.l. while that of Ussita is about $1473 \mathrm{~m}$ a.s.l. This occurs despite the outcropping of BAS is higher in the Ussita catchment than in the Castelsantangelo one, where the average elevation of BAS is only $862 \mathrm{~m}$ a.s.l. This confirms that a high elevation area external to the hydrologic basin (Pian Grande Plain) feeds the creek around point 4. The isotopic data before and after the seismic period, where present, also allowed to identify a slight increase of recharge area mean elevation for springs of the Castelsantangelo creek, which was not observed in the Ussita sub-basin. The $\delta^{18} \mathrm{O}$ measured in point 5 , joined with the results obtained by the tracer tests and the geochemical analysis, confirm that the new mapped fault in the Castelsantangelo creek permits a groundwater connection within the MAI aquifer from the Pian Grande Plain and the bordering slopes towards this sub-basin of the upper Nera River.

\section{Conclusions}

The northern portion of the Mts. Sibillini area, strictly affected by seismic-induced hydrogeological changes after the 2016-2017 earthquake sequence [33], has been interested 
by several research activities: hydro-geochemical and isotopic monitoring, coupled with long time tracer tests and a detailed geo-structural field work.

In this paper, a multi-disciplinary approach applied to the upper Nera basin is presented and this allowed to observe and validate the hydrogeological model for the area.

The role of faults and their interaction with the groundwater flow, especially in seismic active areas, is a challenge aspect in hydrogeology and the application of a single methodology can be misleading. The integrate approach permits to overcame the limits of a single method and join the outcomes of each approach for a better interpretation of the connection between tectonics and hydrogeology.

In particular, the geo-structural features and, more specific, the minor tectonic lineaments can play a non-negligible role that should not be underestimated in the hydrogeological setting and in the analysis of groundwater flow [66].

In this case, a new mapped normal fault (not a regional scale geo-structure) was observed to be responsible for a different hydrodynamic response among the monitoring points in the analysed basins. The role of long-time tracer tests was essential to go more in deep this aspect.

In addition, the new $\delta^{18} \mathrm{O}$-elevation relation has been determined for this area and the geochemical data, coupled with the isotopic ones, permitted to better characterize some of the hydrogeological changes recorded after the seismic period.

This work highlights the importance of performing an integrated approach to refine and validate hydrogeological conceptual model also in different hydrogeological context, especially stressing the hydrogeological modifications due to faults properties and behaviour, in particular before, after and during a seismic period.

Supplementary Materials: The following are available online at https:/ / www.mdpi.com/article/10 $.3390 / w 13111499 / \mathrm{s} 1$.

Author Contributions: Conceptualization, D.F., A.T. and S.P.; methodology, D.F., S.P., A.T.; validation, D.F., F.M., C.C. (Carlo Cardellini) and C.C. (Costanza Cambi); formal analysis, S.C., C.C. (Carlo Cardellini) and D.F.; investigation, D.F., F.M., C.C. (Carlo Cardellini); data curation, D.F., C.C. (Carlo Cardellini) and F.M.; writing — original draft preparation, D.F.; writing—review and editing, D.F., F.M., C.C. (Carlo Cardellini), C.C. (Costanza Cambi), D.V., A.T.; visualization, D.F., F.M., C.C. (Carlo Cardellini); supervision, A.T.; project administration, A.T.; funding acquisition, D.V. and A.T. All authors have read and agreed to the published version of the manuscript.

Funding: This research was financed by Regione Umbria, Italy, Funds for "Interventi di emergenza previsti dall'Ordinanza del Capo del Dipartimento di Protezione Civile del 26 agosto 2016, n. 388".

Institutional Review Board Statement: Not applicable.

Informed Consent Statement: Not applicable.

Data Availability Statement: The data presented in this study are available as supplementary material [s1].

Acknowledgments: The authors kindly acknowledge Mirco Marcellini and Giulio Beddini for the support on field geochemical sampling and analysis and Roberto Checcucci as Regione Umbria project reference.

Conflicts of Interest: The authors declare no conflict of interest.

\section{References}

1. Manga, M.; Brodsky, E.E.; Boone, M. Response of streamflow to multiple earthquakes. Geophys. Res. Lett. 2003, 30. [CrossRef]

2. Charmoille, A.; Fabbri, O.; Mudry, J.; Guglielmi, Y.; Bertrand, C. Post-seismic permeability change in a shallow fractured aquifer following a $\mathrm{M}_{\mathrm{L}} 5.1$ earthquake (Fourbanne karst aquifer, Jura outermost thrust unit, eastern France). Geophys. Res. Lett. $2005,32$. [CrossRef]

3. Shi, Z.; Wang, G.; Wang, C.; Manga, M.; Liu, C. Comparison of hydrological responses to the Wenchuan and Lushan earthquakes. Earth Planet. Sci. Lett. 2014, 391, 193-200. [CrossRef]

4. Goldscheider, N.; Neukum, C. Fold and fault control on the drainage pattern of a double-karst-aquifer system, Winterstaude, Austrian Alps. Acta Carsologica 2010, 39. [CrossRef] 
5. Evans, J.P.; Forster, C.B.; Goddard, J.V. Permeability of fault-related rocks, and implications for hydraulic structure of fault zones. J. Struct. Geol. 1997, 19, 1393-1404. [CrossRef]

6. Fairley, J.; Heffner, J.; Hinds, J. Geostatistical evaluation of permeability in an active fault zone. Geophys. Res. Lett. 2003, 30. [CrossRef]

7. Medici, G.; Smeraglia, L.; Torabi, A.; Botter, C. Review of Modeling Approaches to Groundwater Flow in Deformed Carbonate Aquifers. Groundwater 2020, 59, 334-351. [CrossRef]

8. Bense, V.; Gleeson, T.; Loveless, S.; Bour, O.; Scibek, J. Fault zone hydrogeology. Earth Sci. Rev. 2013, 127, 171-192. [CrossRef]

9. Scibek, J.; Gleeson, T.; McKenzie, J.M. The biases and trends in fault zone hydrogeology conceptual models: Global compilation and categorical data analysis. Geofluids 2016, 16, 782-798. [CrossRef]

10. Xue, L.; Brodsky, E.E.; Erskine, J.; Fulton, P.M.; Carter, R. A permeability and compliance contrast measured hydrogeologically on the San Andreas Fault. Geochem. Geophys. Geosyst. 2016, 17, 858-871. [CrossRef]

11. Fronzi, D.; Di Curzio, D.; Rusi, S.; Valigi, D.; Tazioli, A. Comparison between Periodic Tracer Tests and Time-Series Analysis to Assess Mid- and Long-Term Recharge Model Changes Due to Multiple Strong Seismic Events in Carbonate Aquifers. Water 2020, 12, 3073. [CrossRef]

12. Caine, J.S.; Evans, J.P.; Craig, B.F. Fault zone architecture and permeability structure. Geology 1996, 24, 1025-1028. [CrossRef]

13. Faulkner, D.R.; Jackson, C.A.L.; Lunn, R.J.; Schlische, R.W.; Shipton, Z.K.; Wibberley, C.A.J.; Withjack, M.O. A review of recent developments concerning the structure, mechanics and fluid flow properties of fault zones. J. Struct. Geol. 2010, 32, 1557-1575. [CrossRef]

14. Celico, F.; Petrella, E.; Celico, P. Hydrogeological behaviour of some fault zones in a carbonate aquifer of Southern Italy: An experimentally based model. Terra Nova 2006, 18, 308-313. [CrossRef]

15. Manga, M.; Rowland, J.C. Response of Alum Rock springs to the October 30, 2007 Alum Rock earthquake and implications for the origin of increased discharge after earthquakes. Geofluids 2009, 9, 237-250. [CrossRef]

16. Skelton, A.; Andrén, M.; Kristmannsdóttir, H.; Stockmann, G.; Mörth, C.M.; Sveinbjörnsdóttir, Á.; Jónsson, S.; Sturkell, E.; Guðrúnardóttir, H.R.; Hjartarson, H.; et al. Changes in groundwater chemistry before two consecutive earthquakes in Iceland. Nat. Geosci. 2014, 7, 752-756. [CrossRef]

17. Chiodini, G.; Cardellini, C.; Di Luccio, F.; Selva, J.; Frondini, F.; Caliro, S.; Rosiello, A.; Beddini, G.; Ventura, G. Correlation between tectonic $\mathrm{CO}_{2}$ Earth degassing and seismicity is revealed by a 10-year record in the Apennines, Italy. Sci. Adv. 2020, 6, eabc2938. [CrossRef] [PubMed]

18. Montgomery, D.R.; Manga, M. Streamflow and water well responses to earthquakes. Science 2003, 300, 2047-2049. [CrossRef]

19. Léonardi, V.; Arthaud, F.; Tovmassian, A.; Karakhanian, A. Tectonic and seismic conditions for changes in spring discharge along the Garni right lateral strike slip fault (Armenian Upland). Geodin. Acta 1998, 11, 85-103. [CrossRef]

20. Manga, M.; Beresnev, I.; Brodsky, E.E.; Elkhoury, J.E.; Elsworth, D.; Ingebritsen, S.E.; Mays, D.C.; Wang, C.-Y. Changes in permeability caused by transient stresses: Field observations, experiments, and mechanisms. Rev. Geophys. 2012, 50. [CrossRef]

21. Lai, W.-C.; Koizumi, N.; Matsumoto, N.; Kitagawa, Y.; Lin, C.-W.; Shieh, C.-L.; Lee, Y.-P. Effects of seismic ground motion and geological setting on the coseismic groundwater level changes caused by the 1999 Chi-Chi earthquake, Taiwan. Earth Planets Space 2004, 56, 873-880. [CrossRef]

22. Sanz, E.; Menéndez Pidal, I.; Escavy, J.I.; Ojeda, J.S.D. Hydrogeological Changes along a Fault Zone Caused by Earthquakes in the Moncayo Massif (Iberian Chain, Spain). Sustainability 2020, 12, 9034. [CrossRef]

23. Cox, S.; Rutter, H.; Sims, A.; Manga, M.; Weir, J.; Ezzy, T.; White, P.; Horton, T.; Scott, D. Hydrological effects of the M W 7.1 Darfield (Canterbury) earthquake, 4 September 2010, New Zealand. N. Z. J. Geol. Geophys. 2012, 55, 231-247. [CrossRef]

24. Mohr, C.H.; Manga, M.; Wang, C.-Y.; Korup, O. Regional changes in streamflow after a megathrust earthquake. Earth Planet. Sci. Lett. 2017, 458, 418-428. [CrossRef]

25. Barberio, M.D.; Gori, F.; Barbieri, M.; Billi, A.; Caracausi, A.; De Luca, G.; Franchini, S.; Petitta, M.; Doglioni, C. New observations in Central Italy of groundwater responses to the worldwide seismicity. Sci. Rep. 2020, 10, 17850. [CrossRef] [PubMed]

26. Rojstaczer, S.; Wolf, S. Permeability changes associated with large earthquakes: An example from Loma Prieta, California. Geology 1992, 20, 211-214. [CrossRef]

27. De Luca, G.; Di Carlo, G.; Tallini, M. A record of changes in the Gran Sasso groundwater before, during and after the 2016 Amatrice earthquake, central Italy. Sci. Rep. 2018, 8, 15982. [CrossRef]

28. Adinolfi Falcone, R.; Carucci, V.; Falgiani, A.; Manetta, M.; Parisse, B.; Petitta, M.; Rusi, S.; Spizzico, M.; Tallini, M. Changes on groundwater flow and hydrochemistry of the Gran Sasso carbonate aquifer after 2009 L'Aquila earthquake. Ital. J. Geosci. 2012, $131,459-474$.

29. Amoruso, A.; Crescentini, L.; Petitta, M.; Rusi, S.; Tallini, M. Impact of the 6 April 2009 L'Aquila earthquake on groundwater flow in the Gran Sasso carbonate aquifer, Central Italy. Hydrol. Process. 2010, 25, 1754-1764. [CrossRef]

30. Esposito, E.; Pece, R.; Porfido, S.; Tranfaglia, G. Ground effects and hydrological changes in the Southern Apennines (Italy) in response to the 23 July 1930 earthquake $\left(M_{S}=6.7\right)$. Nat. Hazards Earth Syst. Sci. 2009, 9, 539-550. [CrossRef]

31. Valigi, D.; Fronzi, D.; Cambi, C.; Beddini, G.; Cardellini, C.; Checcucci, R.; Mastrorillo, L.; Mirabella, F.; Tazioli, A. EarthquakeInduced Spring Discharge Modifications: The Pescara di Arquata Spring Reaction to the August-October 2016 Central Italy Earthquakes. Water 2020, 12, 767. [CrossRef] 
32. Mastrorillo, L.; Saroli, M.; Viaroli, S.; Banzato, F.; Valigi, D.; Petitta, M. Sustained post-seismic effects on groundwater flow in fractured carbonate aquifers in Central Italy. Hydrol. Process. 2019, 34, 1167-1181. [CrossRef]

33. Petitta, M.; Mastrorillo, L.; Preziosi, E.; Banzato, F.; Barberio, M.D.; Billi, A.; Cambi, C.; De Luca, G.; Di Carlo, G.; Di Curzio, D.; et al. Water-table and discharge changes associated with the 2016-2017 seismic sequence in central Italy: Hydrogeological data and a conceptual model for fractured carbonate aquifers. Hydrogeol. J. 2018, 26, 1009-1026. [CrossRef]

34. Valigi, D.; Mastrorillo, L.; Cardellini, C.; Checcucci, R.; Di Matteo, L.; Frondini, F.; Mirabella, F.; Viaroli, S.; Vispi, I. Springs discharge variations induced by strong earthquakes: The Mw 6.5 Norcia event (Italy, October 30th 2016). Rendiconti Online Soc. Geol. Ital. 2019, 47, 141-146. [CrossRef]

35. Fronzi, D.; Banzato, F.; Caliro, S.; Cambi, C.; Cardellini, C.; Checcucci, R.; Mastrorillo, L.; Mirabella, F.; Petitta, M.; Valigi, D.; et al. Preliminary results on the response of some springs of the Sibillini Mountains area to the 2016-2017 seismic sequence. Acque Sotter. Ital. J. Groundw. 2020, 9. [CrossRef]

36. Di Matteo, L.; Dragoni, W.; Azzaro, S.; Pauselli, C.; Porreca, M.; Bellina, G.; Cardaci, W. Effects of earthquakes on the discharge of groundwater systems: The case of the 2016 seismic sequence in the Central Apennines, Italy. J. Hydrol. 2020, 583, 124509. [CrossRef]

37. Nanni, T.; Vivalda, P.M.; Palpacelli, S.; Marcellini, M.; Tazioli, A. Groundwater circulation and earthquake-related changes in hydrogeological karst environments: A case study of the Sibillini Mountains (central Italy) involving artificial tracers. Hydrogeol. J. 2020, 28, 2409-2428. [CrossRef]

38. Chiaraluce, L.; Di Stefano, R.; Tinti, E.; Scognamiglio, L.; Michele, M.; Casarotti, E.; Cattaneo, M.; De Gori, P.; Chiarabba, C.; Monachesi, G.; et al. The 2016 Central Italy Seismic Sequence: A First Look at the Mainshocks, Aftershocks, and Source Models. Seism. Res. Lett. 2017, 88, 757-771. [CrossRef]

39. Porreca, M.; Minelli, G.; Ercoli, M.; Brobia, A.; Mancinelli, P.; Cruciani, F.; Giorgetti, C.; Carboni, F.; Mirabella, F.; Cavinato, G.; et al. Seismic Reflection Profiles and Subsurface Geology of the Area Interested by the 2016-2017 Earthquake Sequence (Central Italy). Tectonics 2018, 37, 1116-1137. [CrossRef]

40. Villani, F.; Pucci, S.; Civico, R.; De Martini, P.M.; Cinti, F.; Pantosti, D. Surface Faulting of the 30 October 2016 Mw 6.5 Central Italy Earthquake: Detailed Analysis of a Complex Coseismic Rupture. Tectonics 2018, 37, 3378-3410. [CrossRef]

41. Puliti, I.; Pizzi, A.; Benedetti, L.; Di Domenica, A.; Fleury, J. Comparing Slip Distribution of an Active Fault System at Various Timescales: Insights for the Evolution of the Mt. Vettore-Mt. Bove Fault System in Central Apennines. Tectonics 2020, 39. [CrossRef]

42. Pierantoni, P.; Deiana, G.; Galdenzi, S. Stratigraphic and structural features of the Sibillini Mountains (Umbria-Marche Apennines, Italy). Ital. J. Geosci. 2013, 132, 497-520. [CrossRef]

43. Banzato, F.; Mastrorillo, L.; Nanni, T.; Palpacelli, S.; Petitta, M.; Vivalda, P.M. L'acquifero carbonatico fratturato delle Sorgenti del Fiume Aso (Parco Nazionale dei Monti Sibillini): Valutazioni sulla risorsa rinnovabile e sull'area di alimentazione. In Proceedings of the "La ricerca carsologica in Italia" Laboratorio Carsologico Sotterraneo di Bossea, Frabosa Soprana, Italy, 22-23 June 2013.

44. Mastrorillo, L.; Baldoni, T.; Banzato, F.; Boscherini, A.; Cascone, D.; Checcucci, R.; Boni, C. Quantitative hydrogeological analysis of the carbonate domain of the Umbria Region (Central Italy). Ital. J. Eng. Geol. Environ. 2009, 1, 137-155.

45. Aquilanti, L.; Clementi, F.; Nanni, T.; Palpacelli, S.; Tazioli, A.; Vivalda, P.M. DNA and fluorescein tracer tests to study the recharge, groundwater flowpath and hydraulic contact of aquifers in the Umbria-Marche limestone ridge (central Apennines, Italy). Environ. Earth Sci. 2016, 75, 626. [CrossRef]

46. Viaroli, S.; Mirabella, F.; Mastrorillo, L.; Angelini, S.; Valigi, D. Fractured carbonate aquifers of Sibillini Mts. (Central Italy). J. Maps 2021, 17, 140-149. [CrossRef]

47. Boni, C. Hydrogeological study for identification, characterisation and management of groundwater resources in the Sibillini Mountains National Park (Central Italy). Ital. J. Eng. Geol. Environ. 2010, 2, 21-39.

48. Mastrorillo, L.; Petitta, M. Hydrogeological conceptual model of the upper Chienti River basin aquifers (Umbria-Marche Apennines). Ital. J. Geosci. 2014, 133, 396-408. [CrossRef]

49. Scarpelli, G.; Bellezza, I.; Di Sante, M.; Fratalocchi, E.; Fruzzetti, V.M.E.; Mazzieri, F.; Nanni, T.; Pasqualini, E.; Ruggeri, P.; Sakellariadi, E.; et al. Environmental Sustainability of Engineering Works: Geological and Geotechnical Aspects. In The First Outstanding 50 Years of "Università Politecnica delle Marche"; Springer: Cham, Switzerland, 2019; pp. 259-278.

50. Boni, C.; Petitta, M. Hydrogeological Study for the Identification and Characterization of Aquifers Recharging the Springs of the Perennial Streams of the Sibillini Mountains, Extended to the Whole Area of the National Park; Technical Note; Dipartimento Scienze della Terra, Università La Sapienza di Roma, Autorità di bacino del F. Tevere, Parco Nazionale dei Monti Sibillini: Roma, Italy, 2007.

51. Biella, G.; Lavecchia, G.; Lazey, A.; Pialli, G.; Scarascia, S. First results of the geophysical survey and geological interpretation of the S. Scolastica plain and Piano Grande. Atti I Convegno GNGTS 1981, 293-308.

52. Lippi Boncambi, C. Soil observations on the Sibillini Mountains, in particular on the peaty soils of the Castelluccio di Norcia plain. Boll. Soc. Geol. It. 1950, 69, 26-37.

53. Coltorti, M.; Farabollini, P. Quaternary evolution of the Castelluccio di Norcia basin (Umbro-Marchean Apennines, Italy). Ital. J. Quatern. Sci. 1995, 8, 149-166.

54. Tazioli, A.; Cervi, F.; Doveri, M.; Mussi, M.; Deiana, M.; Ronchetti, F. Estimating the isotopic altitude gradient for hydrogeological studies in mountainous areas: Are the low-yield springs suitable? Insights from the northern Apennines of Italy. Water 2019, 11, 1764. [CrossRef] 
55. Mussi, M.; Nanni, T.; Tazioli, A.; Vivalda, P.M. The Mt Conero limestone ridge: The contribution of stable isotopes to the identification of the recharge area of aquifers. Ital. J. Geosci. 2017, 136, 186-197. [CrossRef]

56. Doveri, M.; Mussi, M. Water isotopes as environmental tracers for conceptual understanding of groundwater flow: An application for fractured aquifer systems in the "Scansano-Magliano in Toscana" area (Southern Tuscany, Italy). Water 2014, 6, $2255-2277$. [CrossRef]

57. Rosen, M.R.; Binda, G.; Archer, C.; Pozzi, A.; Michetti, A.M.; Noble, P.J. Mechanisms of Earthquake-Induced Chemical and Fluid Transport to Carbonate Groundwater Springs after Earthquakes. Water Resour. Res. 2018, 54, 5225-5244. [CrossRef]

58. Giustini, F.; Brilli, M.; Patera, A. Mapping oxygen stable isotopes of precipitation in Italy. J. Hydrol. Reg. Stud. 2016, 8, 162-181. [CrossRef]

59. Tarragoni, C. Determinazione della "quota isotopica" del bacino di alimentazione delle principali sorgenti dell'alta Valnerina. Geol. Romana 2006, 39, 55-62.

60. Nanni, T. Caratteri idrogeologici delle Marche. In L'ambiente Fisico delle Marche; S.E.C.L.A. s.r.l.: Florence, Italy, 1991.

61. ARPA Umbria. Monitoraggio Dell'impatto Ambientale Degli Impianti di Troticoltura in Valnerina-Monitoring of the Environmental Impact of Trout Farms in Valnerina; ARPA Umbria: Terni, Italy, 2002.

62. Madonna, R.; Signanini, P.; Crema, G.; Di Sabatino, B.; Rainone, M.L.; Di Nunzio, A. The geothermal area of Acquasanta Terme (Central Italy): Main characteristics and an attempt of field evaluation. In Proceedings of the World Geothermal Congress 2005, Antalya, Turkey, 24-29 April 2005; pp. 1-8.

63. Williams, P.W. The role of the epikarst in karst and cave hydrogeology: A review. Int. J. Speleol. 2008, 37, 1-10. [CrossRef]

64. Zuber, A.; Motyka, J. Hydraulic parameters and solute velocities in triple-porosity karstic-fissured-porous carbonate aquifers: Case studies in southern Poland. Environ. Earth Sci. 1998, 34, 243-250. [CrossRef]

65. Motyka, J. A conceptual model of hydraulic networks in carbonate rocks, illustrated by examples from Poland. Hydrogeol. J. 1998, 6, 469-482. [CrossRef]

66. López, D.L.; Smith, L. Fluid flow in fault zones: Influence of hydraulic anisotropy and heterogeneity on the fluid flow and heat transfer regime. Water Resour. Res. 1996, 32, 3227-3235. [CrossRef] 